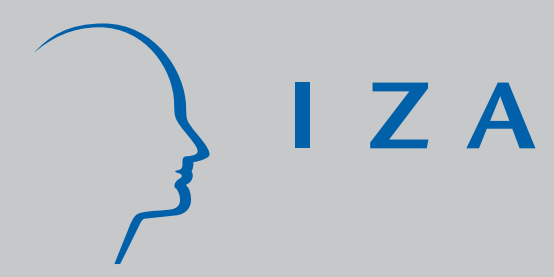

IZA DP No. 148

Employment Effects of Labour Taxation in an Efficiency Wage Model with Alternative Budget Constraints and Time Horizons

Laszlo Goerke

May 2000 


\title{
Employment Effects of Labour Taxation in an Efficiency Wage Model with Alternative Budget Constraints and Time Horizons
}

\author{
Laszlo Goerke \\ Universität Konstanz, Department of Economics and IZA, Bonn
}

\author{
Discussion Paper No. 148 \\ May 2000
}

IZA

P.O. Box 7240

D-53072 Bonn

Germany

Tel.: +49-228-3894-0

Fax: +49-228-3894-210

Email: iza@iza.org

This Discussion Paper is issued within the framework of IZA's research area The Welfare State and Labor Markets. Any opinions expressed here are those of the author(s) and not those of the institute. Research disseminated by IZA may include views on policy, but the institute itself takes no institutional policy positions.

The Institute for the Study of Labor (IZA) in Bonn is a local and virtual international research center and a place of communication between science, politics and business. IZA is an independent, nonprofit limited liability company (Gesellschaft mit beschränkter Haftung) supported by the Deutsche Post AG. The center is associated with the University of Bonn and offers a stimulating research environment through its research networks, research support, and visitors and doctoral programs. IZA engages in (i) original and internationally competitive research in all fields of labor economics, (ii) development of policy concepts, and (iii) dissemination of research results and concepts to the interested public. The current research program deals with (1) mobility and flexibility of labor markets, (2) internationalization of labor markets and European integration, (3) the welfare state and labor markets, (4) labor markets in transition, (5) the future of work, (6) project evaluation and (7) general labor economics.

IZA Discussion Papers often represent preliminary work and are circulated to encourage discussion. Citation of such a paper should account for its provisional character. 
IZA Discussion Paper No. 148

May 2000

\section{ABSTRACT \\ Employment Effects of Labour Taxation in an Efficiency Wage Model with Alternative Budget Constraints and Time Horizons*}

In an efficiency wage economy with variable profits, a shift from payroll to employment taxes will reduce unemployment if the tax level is held constant at the initial wage. However, unemployment will rise if firms are constrained to zero profits in the long-run and if tax revenues are constant. This reversal of employment effects occurs because the shift in taxes reduces wages. This implies a budget deficit. Hence, taxes will have to be raised if revenues are held constant. If the firm's profits cannot change, the tax increase will cause some firms to close down and unemployment will rise. Thus, the predicted employment consequences of changes in the tax structure depend on assumptions about the time-horizon and budget constraint.

JEL Classification: H22, H25, J32, J41

Keywords: Efficiency wages, long-run, short-run, labour taxes

Laszlo Goerke

Universität Konstanz

Department of Economics - D 138

78457 Konstanz

Germany

Tel.: $+49(0) 753188-2137$

Fax:+49(0)753188-3130

Email: Laszlo.Goerke@uni-konstanz.de

\footnotetext{
* I am grateful to B. Rasmussen and seminar participants in Konstanz for comments. Remaining errors are my responsibility.
} 


\section{Introduction}

In a competitive labour market, the equilibrium level of employment is not affected by the structure of taxes on labour costs. This result does not necessarily apply in models of imperfectly competitive labour markets (see Pissarides, 1998, inter alia). Assuming an efficiency wage economy, some authors find that a stronger payroll element at the expense of the employment component raises employment while others obtain opposite predictions. For example, Jackman et al. (1986) argue that a tax on wage increases reduces labour costs and raises employment, given constant tax payments. ${ }^{1}$ However, Rasmussen (1998) has demonstrated that a balanced-budget shift from a payroll to an employment tax increases employment. In this paper, it is shown that the differential predictions are due (a) to alternative time horizons and (b) different notions of budget-neutrality. More specifically, a shift from employment towards payroll taxes will increase employment if the firms' profits are variable and if the government budget need not be balanced ex-post. However, assuming a constant level of profits and a balanced-budget requirement which takes into account wage and employment changes reverses the employment impact of such a tax reform. This reversal happens because the shift in taxes reduces wages. This implies a budget deficit. Taxes have to be increased to balance the budget. If the firms' profits cannot change, the tax increase will cause some firms to close down. Thus, unemployment rises. The model is outlined in Section 2. Moreover, the wage and employment consequences of tax rate variations are calculated. They are used in Section 3 to analyse a reform of labour taxation. Section 4 concludes.

\section{An Economy with Efficiency Wages}

Workers are identical ex-ante and choose the optimal level of effort, given the wage which is set by the firm. Following the frameworks developed by Pisauro (1991) and Rasmussen (1998), effort $\mathrm{e}$ is assumed to be increasing with the wage $\mathrm{w}$ and unemployment $\mathrm{u}$, but rises with the wage at a decreasing rate, and can also depend on other arguments which are unaffected by tax rate variations, such as the monitoring intensity in a shirking framework. Hence, $\mathrm{e}=\mathrm{e}(\mathrm{w}, \mathrm{u}, \cdot)$, where $\mathrm{e}_{\mathrm{W}}>0, \mathrm{e}_{\mathrm{ww}}<0$ and $\mathrm{e}_{\mathrm{u}}>0$ hold, while $\mathrm{e}_{\mathrm{wu}}=0$ applies since utility is assumed to be a linear combination of the (sub-) utility from income and effort. Subsequently, the focus is on an effort function which depends on $w$ and $u$ only to simplify the exposition, implying $\mathrm{e}=\mathrm{e}(\mathrm{w}, \mathrm{u})$. There are $\tau, \tau>>1$, firms in the economy with a given capital stock. The resulting fixed costs are denoted by $h, h>0$. In the short-run, the existence of these fixed costs acts as a barrier or disincentive to the entry or exit of firms. In a longer-term perspective, the entry and exit of firms is allowed for and potentially different fixed costs determine which of the firms enters or leaves the market. Firms are identical, with the exception of the fixed costs $h$. They are characterised by a strictly concave production function $f\left(f^{\prime}>0, f^{\prime \prime}<0\right)$ with effi-

\footnotetext{
${ }^{1}$ See also Johnson and Layard (1986, pp. 967ff), Jackman and Layard (1990), Lockwood and Manning (1993), Carter (1995), Artis and Sinclair (1996), and Goerke (1999) for comparable results not only for efficiency wage models.
} 
ciency units of labour as argument. Firms sell the homogeneous product for a given price, normalised to unity. Labour costs consist of wages $w$, the payroll tax tw, $t>0$, and an employment tax $\mathrm{C}, \mathrm{C}>0$. Thus, profits per firm $\pi$, assumed to be positive in the short-run, are given by:

$$
\pi=f(e(w, u) n)-n(w(1+t)+C)-h
$$

Firms set wages optimally and, given the wage, choose employment to maximise profits. The combination of the first-order conditions yields a (modified) Solow-condition (Solow, 1979):

$$
\mathrm{e}_{\mathrm{w}}[\mathrm{w}(1+\mathrm{t})+\mathrm{C}]-\mathrm{e}(1+\mathrm{t})=0
$$

Equation (2) implies $\mathrm{e}_{\mathrm{W}} \mathrm{W}-\mathrm{e}<0$ since $\mathrm{C}>0$. The expression on the left-hand side of the equality sign in (2) declines with the wage since $\mathrm{e}_{\mathrm{ww}}<0$ has been assumed. The firm's optimal level of employment $\mathrm{n}$ also decreases with the wage $\mathrm{w}$ and the tax rates $\mathrm{t}$ and $\mathrm{C},{ }^{2}$ while it increases with unemployment for $\left(f{ }^{\prime} e n+f^{\prime}\right)>0$, since $n_{u} \equiv \partial n / \partial u=-e_{u}\left(f{ }^{\prime e n}+f^{\prime}\right) /(f$ $" \mathrm{e}^{2}$ ). This is assumed henceforth. Aggregate employment $\mathrm{N}$ is the difference between labour supply normalised to unity and unemployment (or the unemployment rate) $\mathrm{u}, \mathrm{N}=1-\mathrm{u}$, and equals the product of the number of firms $\tau$ and employment per firm $n$. Since effort is a function of wages and unemployment, employment per firm only depends on the tax rates, wages, and the unemployment rate. In equilibrium, the labour market is characterised by:

$$
(1-\mathrm{u})-\tau \mathrm{n}(\mathrm{w}, \mathrm{u}, \mathrm{t}, \mathrm{C})=0
$$

Equation (3) might be labelled labour demand curve. It defines a positive relationship between wages and unemployment if $\mathrm{f}^{\prime} \mathrm{en}+\mathrm{f}^{\prime}>0$ applies (Pisauro, 1991; Carter, 1999). In the shortrun, equations (2) and (3) describe the equilibrium of the efficiency wage economy, where the wage and the unemployment (rate) are the endogenous and the tax rates the exogenous variables. However, in the long-run the number of economic actors is assumed to vary. Thus, firms which incur losses, for example, because of tax increases eventually leave the market and if profits are high, new firms will enter. Hence, the number of firms $\tau$ is a positive function of profits and becomes an endogenous variable, as well. Such a relationship between profits $\pi$ and the number of firms $\tau$ can - in its simplest form - be modelled in the following way:

$$
\mathrm{f}(\mathrm{e}(\mathrm{w}, \mathrm{u}) \mathrm{n})-\mathrm{n}(\mathrm{w}(1+\mathrm{t})+\mathrm{C})-\mathrm{h}-\alpha \tau=0
$$

The parameter $\alpha, \alpha \geq 0$, indicates the responsiveness with which new firms will enter (leave) the market if profits rise (fall). Suppose a tax increase reduces profits. Some firms close down. This reduces labour demand at any given wage. Unemployment goes up. Effort and productivity rise and the profits of the surviving firms return to the original level. If the parameter $\alpha$ is low, only a large reduction in the number of firms and, subsequently, in employment can make the remaining firms profitable again. However, if $\alpha$ is large, the required reduction in

\footnotetext{
2 The labour demand curve in efficiency wage models can be backward bending (Schmidt-Sørensen, 1991; Fehr, 1991), although it definitely has a negative slope in this model for a wage not below the efficiency wage.
} 
labour demand will be comparatively small. Therefore, a low value of $\alpha$ implies a strong reaction of $\tau$ to changes in $\pi$ and indicates a long-term perspective, since the number of firms is stable only in the short-run. A zero profit constraint presupposes $\alpha=0$. The restriction implied by equation (4), therefore, generalises the models by Albrecht and Vroman (1996), Rasmussen (1998), and Goerke (2000).

Equations (2) to (4) yield a system of three equations for the long-run equilibrium in the three unknowns $\mathrm{w}, \mathrm{u}$ and $\tau$. Totally differentiating this system, where the tax rates $\mathrm{t}$ and $\mathrm{C}$ are the exogenous variables and making use of $\mathrm{wn}_{\mathrm{C}}=\mathrm{n}_{\mathrm{t}}=\mathrm{w} /\left(\mathrm{f} " \mathrm{e}^{2}\right)<0$ yields:

$$
\left[\begin{array}{ccc}
\mathrm{e}_{\mathrm{ww}}[\mathrm{w}(1+\mathrm{t})+\mathrm{C}] & -\mathrm{e}_{\mathrm{u}}(1+\mathrm{t}) & 0 \\
-\tau \mathrm{n}_{\mathrm{w}} & -\left(1+\tau \mathrm{n}_{\mathrm{u}}\right) & -\mathrm{n} \\
0 & \mathrm{f}^{\prime} \mathrm{ne}_{\mathrm{u}} & -\alpha
\end{array}\right]\left[\begin{array}{c}
\mathrm{dw} \\
\mathrm{du} \\
\mathrm{d} \tau
\end{array}\right]=\left[\begin{array}{cc}
-\left(\mathrm{e}_{\mathrm{w}} \mathrm{w}-\mathrm{e}\right) & -\mathrm{e}_{\mathrm{w}} \\
\tau \mathrm{wn}_{\mathrm{C}} & \tau \mathrm{n}_{\mathrm{C}} \\
\mathrm{wn} & \mathrm{n}
\end{array}\right]\left[\begin{array}{c}
\mathrm{dt} \\
\mathrm{dC}
\end{array}\right.
$$

The determinant of the short-run system $\mathrm{D}_{S}$ is positive since $\mathrm{n}_{\mathrm{u}}>0$, where $\mathrm{D}_{S}$ is given by $\mathrm{D}_{S}$ $=-\mathrm{e}_{\mathrm{WW}}[\mathrm{w}(1+\mathrm{t})+\mathrm{C}]\left(1+\tau \mathrm{n}_{\mathrm{u}}\right)-\tau \mathrm{n}_{\mathrm{W}} \mathrm{e}_{\mathrm{u}}(1+\mathrm{t})>0$, while the determinant of the long-run system $\mathrm{D}_{l}, \mathrm{D}_{l}=-\alpha \mathrm{D}_{S}+\mathrm{f}^{\prime} \mathrm{n}^{2} \mathrm{e}_{\mathrm{u}} \mathrm{e}_{\mathrm{ww}}(\mathrm{w}(1+\mathrm{t})+\mathrm{C})$, is negative. From equation (5) the following wage effects of higher payroll and employment taxes can be derived, where the subscript $s(l)$ indicates the short-run (longer-term) perspective and use has been made of the expressions for $\mathrm{n}_{\mathrm{C}}, \mathrm{n}_{\mathrm{u}}$, and $\pi_{\mathrm{W}}=\mathrm{f}^{\prime} \mathrm{e}_{\mathrm{W}}-(1+\mathrm{t})=0$ :

$$
\frac{\mathrm{dw}}{\mathrm{dt}}_{\mid s}=\frac{\left(\mathrm{e}_{\mathrm{w}} \mathrm{w}-\mathrm{e}\right)\left(1+\tau \mathrm{n}_{\mathrm{u}}\right)+\tau \mathrm{n}_{\mathrm{t}} \mathrm{e}_{\mathrm{u}}(1+\mathrm{t})}{\mathrm{D}_{s}}<0,
$$

since $\mathrm{e}_{\mathrm{W}} \mathrm{W}-\mathrm{e}<0$ from equation (2).

$$
\begin{aligned}
& \frac{\mathrm{dw}}{\mathrm{dC}}{ }_{s}=\frac{\mathrm{e}_{\mathrm{u}}(1+\mathrm{t}) \tau \mathrm{n}_{\mathrm{C}}+\mathrm{e}_{\mathrm{w}}\left(1+\tau \mathrm{n}_{\mathrm{u}}\right)}{\mathrm{D}_{s}}=\frac{\mathrm{e}_{\mathrm{w}}\left(\mathrm{e}-\mathrm{e}_{\mathrm{u}}(1-\mathrm{u})\right)}{\mathrm{eD}_{s}} \\
& \frac{\mathrm{dw}}{\mathrm{dt}}\left|l_{\mid l}=\frac{\mathrm{ef}^{\prime} \mathrm{n}^{2} \mathrm{e}_{\mathrm{u}}}{\mathrm{D}_{l}}-\alpha \frac{\mathrm{D}_{s}}{\mathrm{D}_{l}} \frac{\mathrm{dw}}{\mathrm{dt}}\right|_{s}=\frac{\mathrm{ef}^{\prime} \mathrm{n}^{2} \mathrm{e}_{\mathrm{u}}}{\mathrm{D}_{l}}-\alpha \frac{\left(\mathrm{e}_{\mathrm{w}} \mathrm{w}-\mathrm{e}\right)\left(1+\tau \mathrm{n}_{\mathrm{u}}\right)+\mathrm{e}_{\mathrm{u}}(1+\mathrm{t}) \tau \mathrm{n}_{\mathrm{t}}}{\mathrm{D}_{l}}<0 \\
& \frac{\mathrm{dw}}{\mathrm{dC}_{\mid l}}=-\alpha \frac{\mathrm{D}_{s}}{\mathrm{D}_{l}} \frac{\mathrm{dw}}{\mathrm{dC}_{\mid s}}=\alpha \frac{\mathrm{e}_{\mathrm{w}}\left(\mathrm{e}_{\mathrm{u}}(1-\mathrm{u})-\mathrm{e}\right)}{\mathrm{eD}_{l}}
\end{aligned}
$$

Wages decline in the short- and the long-run owing to an increase in the payroll tax $t$, while they will rise with the employment tax $C$ if $\mathrm{e}_{\mathrm{u}}(1-\mathrm{u})-\mathrm{e}<0$ holds, unless profits cannot vary. In a zero profit world, $\alpha=0$ implies $d w / d C=0$. Pisauro (1991) has shown that $\mathrm{e}-\mathrm{e}_{\mathrm{u}}(1-\mathrm{u})>$ 0 is a sufficient condition for a positively sloped labour demand curve in the wage - unemployment space. He, therefore, concludes $\mathrm{dw} / \mathrm{dC}_{\mid \mathrm{s}}>0$. However, Carter (1999) has pointed out that Pisauro's specification of the effort function - which differs from the one used here implies that the restriction $\mathrm{e}-\mathrm{e}_{\mathrm{u}}(1-\mathrm{u})>0$ can only hold for an unemployment rate $\mathrm{u}$ in excess of $50 \%$. Therefore, the wage effect of a rise in the employment tax in the short-run might depend on the characteristics of the effort function. ${ }^{3}$ However, none of the employment

\footnotetext{
${ }^{3}$ It can be shown that the assumption e $-e_{u}(1-u)>0$ is also necessary to determine the change in the number of firms owing to tax rate variations in the long-run model.
} 
effects of tax changes or tax reforms is affected by a sign restriction for $\mathrm{e}-\mathrm{e}_{\mathrm{u}}(1-\mathrm{u})$. This can already be seen when deriving the impact of variations in tax rates on unemployment:

$$
\begin{aligned}
& \frac{\mathrm{du}}{\mathrm{dt}}{ }_{s}=\tau \frac{\mathrm{e}_{\mathrm{ww}}[\mathrm{w}(1+\mathrm{t})+\mathrm{C}] \mathrm{wn}_{\mathrm{C}}-\mathrm{n}_{\mathrm{w}}\left(\mathrm{e}_{\mathrm{w}} \mathrm{w}-\mathrm{e}\right)}{\mathrm{D}_{s}} \\
& \left.\frac{\mathrm{du}}{\mathrm{dC}}\right|_{s}=\tau \frac{\mathrm{e}_{\mathrm{ww}}[\mathrm{w}(1+\mathrm{t})+\mathrm{C}] \mathrm{n}_{\mathrm{C}}-\mathrm{n}_{\mathrm{w}} \mathrm{e}_{\mathrm{w}}}{\mathrm{D}_{s}}>0 \\
& \frac{\mathrm{du}}{\mathrm{dt}}=\frac{\mathrm{e}_{\mathrm{ww}}[\mathrm{w}(1+\mathrm{t})+\mathrm{C}] \mathrm{wn}^{2}}{\mathrm{D}_{l}}-\left.\alpha \frac{\mathrm{D}_{s}}{\mathrm{D}_{l}} \frac{\mathrm{du}}{\mathrm{dt}}\right|_{s} \\
& =\frac{\mathrm{e}_{\mathrm{ww}}[\mathrm{w}(1+\mathrm{t})+\mathrm{C}] \mathrm{wn}^{2}}{\mathrm{D}_{l}}-\alpha \tau \frac{\mathrm{e}_{\mathrm{ww}}[\mathrm{w}(1+\mathrm{t})+\mathrm{C}] \mathrm{wn}_{\mathrm{C}}-\mathrm{n}_{\mathrm{w}}\left(\mathrm{e}_{\mathrm{w}} \mathrm{w}-\mathrm{e}\right)}{\mathrm{D}_{l}} \\
& \frac{\mathrm{du}}{\mathrm{dC}_{\mid l}}=\frac{\mathrm{e}_{\mathrm{ww}}[\mathrm{w}(1+\mathrm{t})+\mathrm{C}] \mathrm{n}^{2}}{\mathrm{D}_{l}}-\left.\alpha \frac{\mathrm{D}_{s}}{\mathrm{D}_{l}} \frac{\mathrm{du}}{\mathrm{dC}}\right|_{s} \\
& =\frac{\mathrm{e}_{\mathrm{ww}}[\mathrm{w}(1+\mathrm{t})+\mathrm{C}] \mathrm{n}^{2}}{\mathrm{D}_{l}}-\alpha \tau \frac{\mathrm{e}_{\mathrm{ww}}[\mathrm{w}(1+\mathrm{t})+\mathrm{C}] \mathrm{n}_{\mathrm{C}}-\mathrm{n}_{\mathrm{w}} \mathrm{e}_{\mathrm{w}}}{\mathrm{D}_{l}}>0
\end{aligned}
$$

While an increase in the employment tax $\mathrm{C}$ always raises unemployment, irrespective of the time horizon, a rise in the payroll tax thas ambiguous employment consequences, unless profits are fixed. This is because a rise in $t$ induces a decline in the firms' optimal wage as defined by the Solow-condition (2). Whether the negative employment impact of the higher tax or the positive effect of the lower wage will dominate cannot be ascertained if profits vary.

\section{A Revenue-neutral Reform of Labour Taxation}

Initially, the short-run employment effects of a reform of labour taxation are investigated. Since a change in the structure of labour taxation is to be analysed, and not an alteration in its level, the tax level has to be held constant. Hence, a tax reform which involves a higher payroll tax rate $\mathrm{t}$ will entail a reduction in the employment tax rate $\mathrm{C}$ if higher tax rates increase revenues, such that $\mathrm{C}=\mathrm{C}(\mathrm{t})$ and $\mathrm{dC} / \mathrm{dt}=\mathrm{C}_{\mathrm{t}}<0$ applies.

$$
\frac{\mathrm{du}}{\mathrm{dt}}{ }_{s, \mathrm{C}=\mathrm{C}(\mathrm{t})}=\tau \frac{\mathrm{e}_{\mathrm{ww}}(\mathrm{w}(1+\mathrm{t})+\mathrm{C}) \mathrm{n}_{\mathrm{C}}\left(\mathrm{w}+\mathrm{C}_{\mathrm{t}}\right)-\mathrm{n}_{\mathrm{w}}\left[\mathrm{e}_{\mathrm{w}}\left(\mathrm{w}+\mathrm{C}_{\mathrm{t}}\right)-\mathrm{e}\right]}{\mathrm{D}_{s}}
$$

If the government keeps net revenues per employee $\mathrm{wt}+\mathrm{C}$ constant at the initial wage, that is in an ex-ante sense, as assumed by Jackman et al. (1986), this requirement entails $\mathrm{wdt}+\mathrm{dC}=$ 0 and $\mathrm{w}+\mathrm{C}_{\mathrm{t}}=0$. Hence, in the short-run and for an ex-ante constraint a shift from an employment tax towards a payroll tax creates new jobs (cf. Lockwood and Manning, 1993; Carter, 1995; or Goerke, 1999). The positive employment impact comes about because the wage will unambiguously decline if $\left(\mathrm{w}+\mathrm{C}_{\mathrm{t}}\right)=0$ applies. Wages fall because the combined effect on marginal employment costs of a rise in the payroll tax $t$ and a fall in the employment tax $\mathrm{C}$ is 
zero for $\mathrm{C}_{\mathrm{t}}=-\mathrm{w}$. However, the costs of a wage increase become larger, since they are amplified by the payroll tax. The ensuing reduction in wages lowers unemployment.

The ex-ante constraint on the level of taxes per employee can imply a fall in aggregate tax revenues since the wage induced decline in tax receipts might not be compensated by the employment induced rise in revenues. Suppose, therefore, that the government takes into account all changes in wages and employment owing to the tax variations. Let the budget of the government, in which for simplicity all other taxes than $t$ and $C$ and all outlays except for unemployment compensation $\mathrm{b}$ are ignored, be denoted by $\mathrm{B}$, where $\mathrm{B} \equiv(\mathrm{tw}+\mathrm{C})(1-\mathrm{u})-\mathrm{ub}=0$. $\mathrm{A}$ balanced-budget reduction in $\mathrm{C}$ to compensate for a rise in $\mathrm{t}$ implies $\mathrm{dB}=0$ and is defined by:

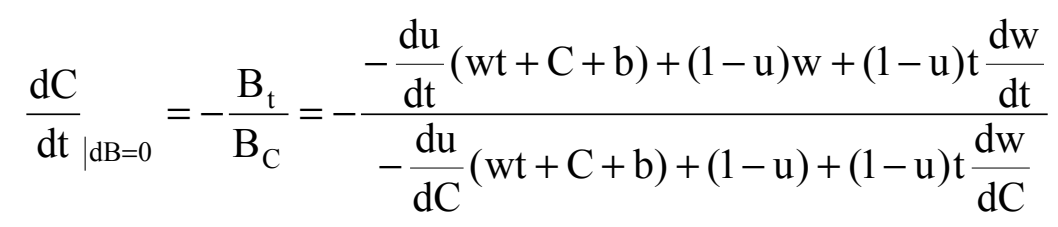

The changes in wages and unemployment which have to be incorporated into the computation of $\mathrm{dC} / \mathrm{dt}$ are given by equations $(6 \mathrm{a} / 6 \mathrm{~b})$ and $(7 \mathrm{a} / 7 \mathrm{~b})$ for the short-run analysis and by $(6 \mathrm{c} / 6 \mathrm{~d})$ and $(7 \mathrm{c} / 7 \mathrm{~d})$ for the long-run investigation. Under the plausible assumption that an increase in either of the tax rates raises revenues $B_{t}, B_{C}>0$ and $C_{t}<0$ hold. Substituting in accordance with $(6 a / 6 b)$ and $(7 a / 7 b)$, the balanced-budget requirement implies for the short-run case:

$$
\left(\mathrm{w}+\mathrm{C}_{\mathrm{t}}\right)_{s}=\frac{\tau \mathrm{ez}}{\mathrm{B}_{\mathrm{C}} \mathrm{D}_{s}}, \text { for } \mathrm{z} \equiv \mathrm{n}\left(1+\tau \mathrm{n}_{\mathrm{u}}\right) \mathrm{t}+\mathrm{n}_{\mathrm{w}}(\mathrm{wt}+\mathrm{C}+\mathrm{b})
$$

Since the variable $\mathrm{z}$ and, thus, the budgetary effects of the ex-ante constraint cannot be signed, the unemployment consequences of a rise in $t$ as determined by equation (8) are ambiguous. This potential change in the employment effects of a reform of labour taxation occurs because holding constant tax payments per employee at the initial wage induces a wage reduction such that aggregate tax revenues fall. However, employment rises. Whether these changes require a rise or a fall in, for example, the employment tax relative to the ex-ante case in order to balance the budget cannot be determined. Therefore, the change in labour costs which is induced by the tax reform in conjunction with the balanced-budget restriction, and the variation in unemployment are ambiguous in the short-run.

In a longer-term perspective, the number of firms is assumed to vary. For $C=C(t)$, the change in unemployment owing to a reform of labour taxation can be computed from equation (5):

$$
\begin{aligned}
\frac{\mathrm{du}}{\mathrm{dt}} \mid l, \mathrm{C}=\mathrm{C}(\mathrm{t}) & \frac{\mathrm{e}_{\mathrm{ww}}(\mathrm{w}(1+\mathrm{t})+\mathrm{C})\left(\mathrm{w}+\mathrm{C}_{\mathrm{t}}\right) \mathrm{n}^{2}}{\mathrm{D}_{l}} \\
& +\alpha \tau \frac{\left(\mathrm{w}+\mathrm{C}_{\mathrm{t}}\right)\left[\mathrm{e}_{\mathrm{w}} \mathrm{n}_{\mathrm{w}}-\mathrm{e}_{\mathrm{ww}}(\mathrm{w}(1+\mathrm{t})+\mathrm{C}) \mathrm{n}_{\mathrm{C}}\right]}{\mathrm{D}_{l}}-\alpha \tau e \frac{\mathrm{n}_{\mathrm{w}}}{\mathrm{D}_{l}}
\end{aligned}
$$

For $\mathrm{w}+\mathrm{C}_{\mathrm{t}} \leq 0$ and $\alpha>0$ unemployment falls due to a restructuring of labour taxation since the budget requirement allows for a sufficient reduction in $\mathrm{C}$. If taxes per employee are held constant ex-ante $\left(\mathrm{w}+\mathrm{C}_{\mathrm{t}}=0\right)$, wages will decline. Although labour costs shrink, the rise in 
employment and the ensuing reduction in effort more than compensate the positive profit effect of lower wages. The number of firms is reduced. Employment per firm must rise. However, as long as profits can vary $(\alpha>0)$, the increase in employment per firm is strong enough to warrant a reduction in unemployment owing to an increase in the payroll tax, holding taxes constant at the initial wage, as evidenced by the last term in (11). If profits are rigid $(\alpha=0)$, a shift in labour taxation will have no employment effect for $\mathrm{w}+\mathrm{C}_{\mathrm{t}}=0$, while the number of firms declines. ${ }^{4}$ If an ex-post budget constraint is imposed, $\left(\mathrm{w}+\mathrm{C}_{\mathrm{t}}\right)$ has to be computed using equations $(6 \mathrm{c} / 6 \mathrm{~d})$ and $(7 \mathrm{c} / 7 \mathrm{~d})$ :

$$
\left(\mathrm{w}+\mathrm{C}_{\mathrm{t}}\right)_{l}=-\frac{(1-\mathrm{u}) \mathrm{tef}^{\prime} n^{2} \mathrm{e}_{\mathrm{u}}}{\mathrm{B}_{\mathrm{C}} \mathrm{D}_{l}}-\alpha \frac{\tau \mathrm{ez}}{\mathrm{B}_{\mathrm{C}} \mathrm{D}_{l}},
$$

for $\mathrm{z}$ as defined in (10). The consequences of a reform of labour taxation are generally ambiguous when the number of firms varies. However, for a zero profit constraint $\alpha=0$ holds and the employment effects of an increase in the payroll tax and a reduction in the employment tax are determined solely by the wage change. Substituting in (11) in accordance with equation (12) yields:

$$
\left.\frac{\mathrm{du}}{\mathrm{dt}}\right|_{\substack{l, \mathrm{C}=\mathrm{C}(\mathrm{t}) \\ \alpha=0}}=\frac{\mathrm{e}_{\mathrm{ww}}(\mathrm{w}(1+\mathrm{t})+\mathrm{C}) \mathrm{n}^{2}\left(\mathrm{w}+\mathrm{C}_{\mathrm{t}}\right)_{l}}{\mathrm{D}_{l}}=-\frac{\mathrm{e}_{\mathrm{ww}}(1-\mathrm{u}) \mathrm{tef}^{\prime} \mathrm{n}^{4} \mathrm{e}_{\mathrm{u}}(\mathrm{w}(1+\mathrm{t})+\mathrm{C})}{\mathrm{B}_{\mathrm{C}}\left(\mathrm{D}_{l}\right)^{2}}>0
$$

Equation (13) shows that unemployment will rise in the long-run if a payroll tax is substituted for an employment tax. The number of firms will shrink unambiguously if $\mathrm{e}-\mathrm{e}_{\mathrm{u}}(1-\mathrm{u})>0$ holds. The superior job performance of an employment tax relative to a payroll tax - as derived by Rasmussen (1998) - will only hold if the budget has to be balanced ex-post and if profits cannot vary at all (see also Rasmussen (1997)). The zero profit requirement implies that any change in the level of taxes cannot be born by firms. Since a shift from employment to payroll taxes, combined with an ex-ante constraint, reduces the firm's optimal wage for a given level of unemployment and leaves employment unaffected for $\alpha=0$ (cf. equations (2) and (11)), the budget requirement necessitates a rise in taxes. This reduces employment. Moreover, it has been shown above that the balanced-budget employment effects are ambiguous in the short-run. The differential employment consequences of changes in the structure of labour taxation in the short and the long-run, therefore, depend (a) on the strictness of the budget constraint and (b) on the existence of a zero-profit economy, but not on the assumption of a variable number of firms. The employment effects for the various combinations of restrictions are summarised below:

\footnotetext{
${ }^{4}$ See Goerke (1997). Imposing the zero profit constraint does not have this employment consequence in Jackman et al. (1986), Jackman and Layard (1990), and Johnson and Layard (1986), since a different effort function is assumed, inter alia.
} 
Table 1: Employment Effects of a Shift from Employment to Payroll Tax for Alternative Budget Constraints and Time Horizons

\begin{tabular}{|l|c|c|}
\hline & \multicolumn{2}{|c|}{ Budget Constraint } \\
\hline Time Horizon & Tax per Employee Constant Ex-ante & Balanced-Budget \\
\hline Fixed \# of Firms, Variable Profits & + & $?$ \\
\hline Variable \# of Firms, Variable Profits & + & $?$ \\
\hline Variable \# of Firms, Constant Profits & 0 & - \\
\hline
\end{tabular}

Graphically, the results can be illustrated as follows: From equation (2) the Solow-condition implies a trade-off between wages and unemployment and is characterised by a negative slope in the wage - unemployment space, while the labour demand curve (LD) slopes upwards for $\mathrm{n}_{\mathrm{u}}>0$. Moreover, the profit constraint (4) can be combined with the LD curve (3) for the long-run analysis, to yield a long-run labour demand curve LLD, which is given by $(1-u)-n \pi$ $/ \alpha=0$. This long-run labour demand curve LLD has a greater positive slope than the LD curve and becomes steeper the lower the value of $\alpha$ is. For $\alpha=0$, solely the profit constraint (4) determines labour demand and implies a vertical LLD curve, since $\mathrm{dw} / \mathrm{du}=-\pi_{\mathrm{u}} / \pi_{\mathrm{W}}$, where $\pi$ $\mathrm{w}=0$ from the firm's first-order condition. ${ }^{5}$ The curves are depicted in figure 1.

Figure 1: Employment Effects of Shift from Employment to Payroll Taxes

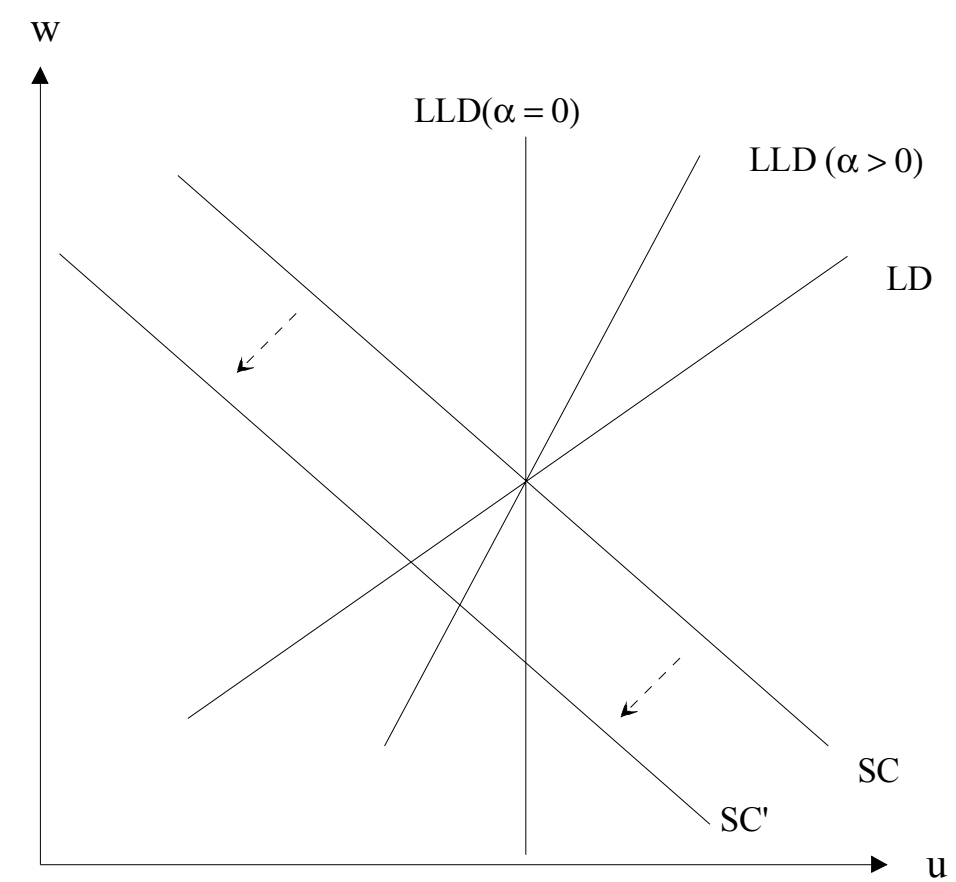

\footnotetext{
5 The vertical LLD curve does not result in a framework with a dichotomous effort function, such as the one by Albrecht and Vroman (1996). This is because firms cannot adjust wages at the margin, implying $\pi_{\mathrm{W}} \neq 0$. Thus, the fraction of employees who shirk is independent of unemployment, and $\pi_{\mathrm{u}}=0$. The resulting LLD is horizontal in the wage-unemployment space. The long-run properties of shirking models with a dichotomous effort decision might, thus, differ from those with a continuous relationship between wages and productivity.
} 
A shift from employment to payroll taxes, holding constant tax payments ex-ante, moves the Solow-condition downwards from SC to $\mathrm{SC}^{\prime}$ in figure 1. If profits are rigid, wages will fall but unemployment will not change. But if profits can vary, unemployment will fall. If, instead of an ex-ante constraint, a balanced-budget requirement is imposed, the potential increase in taxes - relative to the tax level resulting in the ex-ante case - might shift the Solow-condition upwards again and the labour demand curve(s) to the right. For a positively sloped labour demand curve, the imposition of a balanced-budget constraint, therefore, implies uncertain employment effects. However, for $\alpha=0$ the downward movement of the Solow-condition does not create jobs such that tax rates have to be raised with certainty. The rightward shift of the LLD curve entails a rise in unemployment.

\section{Conclusions}

A shift from employment taxes to payroll taxes raises employment in the short-run if the government does not insist on an ex-post balanced-budget. This mirrors the result that a higher degree of tax progressivity, holding constant taxes at the initial wage, raises employment. In the long-run, when the entry and exit of firms is feasible, the positive employment impact will survive if tax payments per employee are held constant at the initial wage and if profits can still vary. If, however, an ex-post balanced-budget restriction is imposed, the employment effects of a stronger payroll element in labour taxation at the expense of the employment component will be reversed and the number of jobs will shrink if firms face a zero profit constraint. In contrast to the conjecture by Pissarides (1998, p.179), that "the gains from a revenue-neutral reform come close to a 'free lunch' ", a statement which, however, Pissarides does not apply to his specific efficiency wage model with a dichotomous decision over effort, also a change in the structure of taxation does not yield benefits without costs. 


\section{References}

Albrecht, J. W. and Vroman, S. B. (1996). 'A note on the long-run properties of the shirking model', Labour Economics, Vol. 3, pp. 189-195.

Artis, M. J. and Sinclair, P. J. N. (1996). 'Labour subsidies: a new look', Metroeconomica, Vol. 47, pp. 105-124.

Carter, T. J. (1995). 'Efficiency wages: employment versus welfare', Southern Economic Journal, Vol. 62, pp. 116-125.

Carter, T. J. (1999). 'The effect of taxes on labour in efficiency wage models: a comment', Journal of Public Economics, Vol. 72, pp. 325-327.

Fehr, E. (1991). 'Wages and labour demand: a note', Journal of Institutional and Theoretical Economics, Vol. 147, pp. 539-546.

Goerke, L. (1997). 'Taxes in an efficiency wage economy in the short-run and in the long-run', Finanzarchiv, Vol. 54, pp. 447-470.

Goerke, L. (1999). 'Efficiency wages and taxes', Australian Economic Papers, Vol. 38, pp. 131-142.

Goerke, L. (2000). 'On the structure of unemployment benefits in shirking models', Labour Economics, Vol. 7, pp. 283-295.

Jackman, R. and Layard, P. R. G. (1990). 'The real effects of tax-based incomes policy', Scandinavian Journal of Economics, Vol. 92, pp. 309-324.

Jackman, R., Layard, P. R. G. and Pissarides, C. A. (1986). 'Policies for reducing the natural rate of unemployment', in: Butkiewicz, J. L., Koford, K. J. and Miller, J. B. (eds), Keynes' Economic Legacy, New York: Praeger Publishers, pp. 111-133.

Johnson, G. E. and Layard, P. R. G. (1986). 'The natural rate of unemployment - explanation and policy', in: Ashenfelter. O. and Layard, P. R. G. (eds), Handbook of Labor Economics Vol. II, Amsterdam: North Holland, pp. 921-999.

Lockwood, B. and Manning, A. (1993). 'Wage setting and the tax system', Journal of Public Economics, Vol. 52, pp. 1-29.

Pisauro, G. (1991). 'The effect of taxes on labour in efficiency wage models', Journal of Public Economics, Vol. 46, pp. 329-345.

Pissarides, C. A. (1998). 'The impact of employment tax cuts on unemployment and wages; the role of unemployment benefits and tax structure', European Economic Review, Vol. 42, pp. 155-183.

Rasmussen, B. S. (1997). 'Non-equivalence of employment and payroll taxes in imperfectly competitive labour markets', University of Aarhus, Working Paper 1997-22.

Rasmussen, B. S. (1998). 'Long run effects of employment and payroll taxes in an efficiency wage model', Economics Letters, Vol. 58, pp. 245-253.

Schmidt-Sørensen, J. B. (1991). 'Wages, work effort and unemployment', Cyprus Journal of Economics, Vol. 4, pp. 78-86.

Solow, R. M. (1979). 'Another possible source of wage stickiness', Journal of Macroeconomics, Vol. 1, pp. 79-82. 


\section{IZA Discussion Papers}

No. Author(s)

51

A. Barrett

P. J. O'Connell

52 J. Mayer

R. T. Riphahn

53

J. Hartog

P. T. Pereira

J. A. C. Vieira

54 M. Lofstrom

55

L. Goerke

56

A. Lindbeck

D. J. Snower

57

I. N. Gang

K. F. Zimmermann

58

T. Bauer

K. F. Zimmermann

59

D. J. DeVoretz

S. A. Laryea

60

C. Belzil

J. Hansen

61

R. Winkelmann

62

A. Thalmaier

63

M. Ward

64

M. Ward

65

H. Lehmann

J. Wadsworth

A. Acquisti

66

E. J. Bird

H. Kayser

J. R. Frick

G. G. Wagner
Title

Area

Date

Does Training Generally Work?

5

$8 / 99$

The Returns to In-Company Training

Fertility Assimilation of Immigrants: Evidence

3

$8 / 99$

from Count Data Models

Inter-industry Wage Dispersion in Portugal: high

but falling

$8 / 99$

Labor Market Assimilation and the

$8 / 99$

Self-Employment Decision of Immigrant

Entrepreneurs

Value-added Tax versus Social Security

Contributions

Centralized Bargaining and Reorganized Work:

Are they compatible?

Is Child like Parent?

Educational Attainment and Ethnic Origin

9/99

Occupational Mobility of Ethnic Migrants

$9 / 99$

Canadian Immigration Experience:

Any Lessons for Europe?

Subjective Discount Rates, Intergenerational

Transfers and the Return to Schooling

Immigration: The New Zealand Experience

$10 / 99$

Bestimmungsgründe von Fehlzeiten: Welche

Rolle spielt die Arbeitslosigkeit?

1/2/3 9/99

6

$10 / 99$

Your Everyday, Average Academic

$10 / 99$

Salary and the Gender Salary Gap in the Academic Profession

Grime and Punishment: Job Insecurity and Wage 4

Arrears in the Russian Federation

$10 / 99$

The Immigrant Welfare Effect: Take-Up or

3

$10 / 99$ 

of Wage Differentials Transition Economies

\section{0 \\ J. C. van Ours}

J. Veenman
The Netherlands: Old Emigrants - Young Immigrant Country

Migration, Migrants and Policy in the United Kingdom

Privacy, time consistent optimal labor income taxation and education policy

Female Labour Supply, Flexibility of Working Hours, 1 and Job Mobility in the Netherlands

The Heterogeneity and Cyclical Sensitivity of 1 Unemployment: An Exploration of German Labor Market Flows 

Adversity

91 M. Lechner

Tenures that Shook the World: Worker Turnover in $\quad 4$ Russia, Poland and Britain

Identification and Estimation of Causal Effects of

An Evaluation of Public-Sector-Sponsored

Continuous Vocational Training Programs in East

N. Smith 
107 J. C. van Ours G. Ridder

J. Boone

J. C. van Ours

109 G. J. van den Berg

B. van der Klaauw

110 D. DeVoretz

C. Werner

111 V. Sorm

K. Terrell

L. Bellmann

T. Schank

113 R. Euwals

114 G. Brunello

A. Medio

115 A. Cigno

F. C. Rosati

116

C. Belzil

A. Haas

C. Klose

118 M. A. Shields

M. E. Ward

119 A. Lindbeck

D. J. Snower

120 P. T. Pereira

P. S. Martins

121 J. C. van Ours
Fast Track or Failure: A Study of the Completion

Rates of Graduate Students in Economics

Modeling Financial Incentives to Get Unemployed Back to Work

Combining Micro and Macro Unemployment

3

$1 / 00$

Duration Data

A Theory of Social Forces and Immigrant Second

1

$2 / 00$

Language Acquisition

Sectoral Restructuring and Labor Mobility:

A Comparative Look at the Czech Republic

Innovations, Wages and Demand for

5

$2 / 00$

Heterogeneous Labour: New Evidence from a

Matched Employer-Employee Data-Set

Do Mandatory Pensions Decrease Household

Savings? Evidence for the Netherlands

An Explanation of International Differences in

Education and Workplace Training

Why do Indian Children Work, and is it Bad for

3

$2 / 00$

Them?

Unemployment Insurance and Subsequent Job

3

$2 / 00$

Duration: Job Matching vs. Unobserved

Heterogeneity

IAB Employment Subsample 1975-1995.

Opportunities for Analysis Provided by the

Anonymised Subsample

Improving Nurse Retention in the British National

5

$2 / 00$

Health Service: The Impact of Job Satisfaction on Intentions to Quit

The Division of Labor and the Market for

Organizations

Does Education Reduce Wage Inequality?

5

Quantile Regressions Evidence from Fifteen

European Countries

Do Active Labor Market Policies Help Unemployed Workers to Find and Keep Regular Jobs? 
Rational Poverty or Poor Rationality? The Take-up of Social Assistance Benefits

125 F. Büchel

The Income Portfolio of Immigrants in Germany -

Effects of Ethnic Origin and Assimilation. Or:

J. R. Frick

126 J. Fersterer

R. Winter-Ebmer

Who Gains from Income Re-Distribution?

127 M. Karanassou

D. J. Snower

Smoking, Discount Rates, and Returns to

Education

Characteristics of Unemployment Dynamics: The

Chain Reaction Approach

128 O. Ashenfelter

D. Ashmore

O. Deschênes

Do Unemployment Insurance Recipients Actively

Seek Work? Evidence From Randomized Trials in

Four U.S. States

129 B. R. Chiswick

M. E. Hurst

C. Lucifora

The Employment, Unemployment and Unemployment Compensation Benefits of Immigrants

The Returns to Education in Italy: A New Look at the Evidence

Are Immigrants Favorably Self-Selected? An

134 A. D. Kugler

G. Saint-Paul

135 A. Barrett P. J. O'Connell

136 M. Bräuninger M. Pannenberg

Is There a Wage Premium for Returning Irish

Unemployment and Productivity Growth: An

Empirical Analysis within the Augmented Solow 
141 R. Hujer

M. Wellner

142 J. J. Dolado

F. Felgueroso

J. F. Jimeno

143 P. J. Luke

M. E. Schaffer

144 G. Saint-Paul

145 M.-S. Yun

146 T. K. Bauer

J. P. Haisken-DeNew

147 M. Belot

J. C. van Ours

148 L. Goerke
The Effects of Public Sector Sponsored Training on

Individual Employment Performance in East

Germany

Explaining Youth Labor Market Problems in Spain: 3

Crowding-Out, Institutions, or Technology Shifts?

Wage Determination in Russia: An Econometric 4

Investigation

Flexibility vs. Rigidity: Does Spain have the worst of 1 both Worlds?

Decomposition Analysis for a Binary Choice Model 7

Employer Learning and the Returns to Schooling 5

Does the Recent Success of Some OECD 3

Countries in Lowering their Unemployment Rates

Lie in the Clever Design of their Labour Market

Reforms?

Employment Effects of Labour Taxation in an Efficiency Wage Model with Alternative Budget Constraints and Time Horizons
$4 / 00$

$4 / 00$

$4 / 00$

$4 / 00$

$4 / 00$

$4 / 00$

$4 / 00$

$5 / 00$

An updated list of IZA Discussion Papers is available on the center's homepage www.iza.org. 